\section{荿王道路開通にとあなう温泉地の発展}

\section{長谷川 典 夫}

温泉地は, 利用客の増加, 客による消費額の 增加, 通年的利用 (利用の季節的変動の減少) など を必要条件として集落の発展をみる。

筆者は, 広域観光交通路の開発にともなら温 泉地発展の事例として, 宮城県の遠刈田・青根 および峨々の 3 温泉地をとりあげ, 蔵王道路開 設前後の 1961〜1963 年の利用客数の変化を調 べた。

宮城県側より蔵王山頂へ至る通常利用経路は すべて遠刚田を経由し, その西方で2 分した道 路は，一方が青根・峨々を連ねて再び合し，峨 々南方で有料の蔵王道路に続き, 山形県上山市 に通じる。

遠刈田は, 1961 年の利用客 58,496 人，5ち 宮城県内客が 90\% を占める典型的な湯治場で あったが，蔵王道路宮城県側の 開通した 1962 年には利用客は 113,188 人に著增，その5ち県 内客は $80 \%$ 增にとどまったのに対し，県外客 は約 10 倍に増え, 県内客比は50\%に減じた。 全道開通の 1963 年の利用客は $30 \%$ 増にとどま ったが，県内客比は 20\% に減じ，県外客は前 年のさらに 2 倍に増加して，道路に接続する山 形県からの 40\%（県外客構成比）をはじめ, 関東 30\%を含むかなり広域的利用客を有するに至 った。

遠刈田と対照的に，青根は 1961 年当時 $60 \%$ が県外客で占められ, 福島・山形・茨城の各県 からの来客多く，遠刈田より広域な利用客を集 めていた。しかし 1962 年の利用客数 100, 506 人の内訳を見れば，県内客の $50 \%$ 増に対して 県外客数に大きな变化なく，その比率はほぼ相 半ばし, 利用客分布からは遠刚田とは逆の傾向 を示した。しかし 1963 年には県内客の減少と 県外客の 50\% 增によって, その比率は 3 対 7 と変じ, 山形・福島・秋田の各県より打の沶の 20\%，関東その他より 40\% の県外客構成をみ

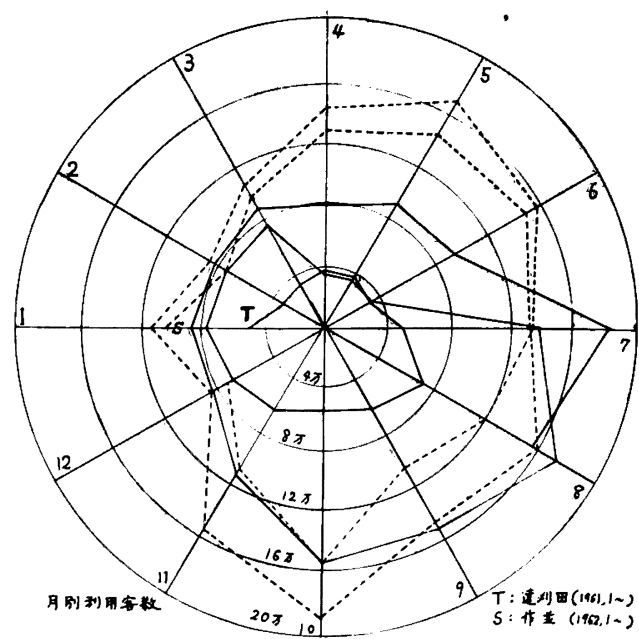

るに至り，遠刚閂と類似の傾向を示し始めた。 峨々は収容力が小さく、利用客は漸增したが, 大きな変化はなかった。

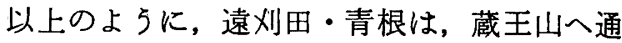
じる交通路の整備により, 観光ルートの宿泊拋 点としての性格を強めた結果, 利用客の增加と その居住地分布の広域化がみられた。一方。観 光基地としての性格上, 利用客数の季節的変動 は,やや減じつつあるとは言え, いぜんこして 大きい。

いま, 上記 2 温泉の利用客数・利用客居住地 分布・利用の季節性の3 つの点でその变化を, 集落の人口・家屋数・業種構成の変化之対照さ せ，かつ作苝・秋保その他の温泉地々比較して 考えれば，次の観点が生まれてくる。すなわ ち, 木内による季節性 (1940) 打上び社会圈 (1942) による温泉集落の分類は, その性格分類である とともに，ある温泉地についての，また幾つか の温泉地の比較における, 発展段階による類型 化の意味を含むと考えてよいと思われる。

(1968. 11. 8 受理)

\title{
Increase of Visitors to Tokatta and Aone Spas due to the Opening of Zao-Highway
}

\section{Norio Hasegawa}

On the eastern slopes of Zao Volcano, there are three hot-spring spas along the road leading from Sendai city to Zao Volcano. They are Tokatta, Aone and Gaga. In April, 1963, for the development of tourist industry, the whole line of Zao-Highway was opened to traffic from Tokatta to Kaminoyama city, Yamagata Prefecture, via the top of Zao Volcano. Since then, the tourists visiting these spas have been rapidly increased. For exmaple, in the case of Tokatta, the visitors increased from 58,500 in 1961 to 146,000 in 1963 . At the same time, the areal distribution of the visitors' homes has become more extensive. 